\title{
Prevalence of coagulase-negative staphylococci in bovine mastitis in Zimbabwe
}

\author{
T Kudinha $^{\mathrm{a}}$ and C Simango ${ }^{\mathrm{b}^{*}}$
}

\begin{abstract}
This study was carried out to determine the prevalence of coagulase-negative staphylococci in clinical and subclinical mastitis in commercial and small-scale farms in Zimbabwe. Thirty five quarter milk samples from clinical mastitis cases and 371 quarter milk samples from cows with subclinical mastitis were cultured for bacterial pathogens. The most frequent pathogens isolated in clinical mastitis were the enteric bacteria (31.4\%), followed by coagulase negative staphylococci $(22.9 \%)$ and then Staphylococcus aureus (17.1\%), whereas in subclinical mastitis S. aureus $(34.2 \%)$ and coagulase-negative staphylococci were $(33.2 \%)$ the most common. Bacillus species were only isolated in milk samples from subclinical mastitis. Coagulase-negative staphylococci were observed in mixed infections with other bacteria in only $2.2 \%$ of the 406 milk samples from clinical and subclinical mastitis where they were isolated together with Bacillus species in 6 of the 9 mixed infection cases. About $95 \%$ of the milk samples from which 131 coagulase-negative staphylococci were isolated had correspondingly high somatic cell counts. The coagulase-negative staphylococci isolated most frequently were S. chromogenes $(7.9 \%)$, S. epidermidis $(7.4 \%)$ and S. hominis (5.9\%). They were all associated with high somatic cell counts. All the coagulase-negative staphylococci isolates were susceptible to cloxacillin and erythromycin, and more than $90 \%$ of the isolates were susceptible to neomycin, penicillin and streptomycin. The highest resistance was to tetracycline (17.6\%), followed by lincomycin (13.7 \%). About $8 \%$ of the isolates were resistant to both penicillin and streptomycin.
\end{abstract}

Key words: aetiology, bovine mastitis, coagulase-negative staphylococci, resistance.

Kudinha T, Simango C Prevalence of coagulase-negative staphylococci in bovine mastitis in Zimbabwe. Journal of the South African Veterinary Association (2002) 73(2): $62-65$ (En.). Department of Veterinary Services, PO Box CY 551, Causeway, Harare, Zimbabwe.

\section{INTRODUCTION}

Bovine mastitis is nearly always caused by microorganisms. Most of the infections have been associated with Staphylococcus aureus, Streptococcus agalactiae, S. dysgalactiae and S. uberis ${ }^{6}$. S. aureus has been shown to be the most common cause of clinical bovine mastitis. In Zimbabwe, $S$. aureus was observed to be the most common cause of clinical bovine mastitis in studies carried out in cattle on both commercial farms and those owned by peasant farmers, with Streptococcus species and enteric bacteria being the other important pathogens ${ }^{1,4,9}$.

Unlike coagulase-positive Staphylococcus aureus, coagulase-negative staphylococci are of low virulence, and are rarely associated with clinical disease, although they frequently produce an inflammatory response measurable as an elevated somatic

aDepartment of Veterinary Services, PO Box CY 551 Causeway, Harare, Zimbabwe.

bDepartment of Medical Laboratory Sciences, University of Zimbabwe Medical School, PO Box A 178, Avondale, Harare, Zimbabwe.

*Author for correspondence. E-mail: dmlt@healthnet.zw Received: February 2001. Accepted: January 2002. cell count in the milk. Coagulase-negative staphylococci are frequently isolated from milk samples aseptically collected from the udder. In Zimbabwe, coagulase-negative staphylococci were isolated in $7 \%$ of 371 milk samples collected from peasant farmers; $3.2 \%$ of the isolates were associated with high somatic cell counts $\left(>6 \times 10^{6}\right.$ leucocytes $\left./ \mathrm{m} \ell\right)$, but only in 1 instance were coagulase-negative staphylococci associated with clinical mastitis?.

In dairy herds in Bloemfontein, South Africa, coagulase-negative staphylococci were isolated in $11.9 \%$ of milk samples from cows with subclinical mastitis; $55 \%$ of the isolates were associated with somatic cell counts exceeding $1.0 \times 10^{6} / \mathrm{m} \ell^{11}$. The frequent occurrence of coagulasenegative staphylococci in samples with high somatic cell counts suggested that these organisms are more pathogenic than is generally assumed.

The aim of this study was to determine the prevalence of coagulase-negative staphylococci in clinical and subclinical bovine mastitis in large commercial and small-scale dairy farms in Zimbabwe and to determine the antibiotic susceptibilities of the isolates.

\section{MATERIALS AND METHODS}

\section{Collection of milk samples}

The study was carried out in 13 smallscale and commercial dairies in Mashonaland Central, Mashonaland West and Manicaland provinces of Zimbabwe. A sample of milk from each lactating quarter of each cow in the milking herd was aseptically collected and processed separately in the laboratory. Each teat was cleaned with running water, wiped dry with individual paper towels, and disinfected with $70 \%$ ethyl alcohol on cotton wool. After discarding the first few streams of milk, samples were collected by the normal hand-milking technique in sterile bottles. Each udder was examined for signs of clinical mastitis and each quarter milk sample was examined for abnormal colour and presence of clots. The milk samples were transported to the laboratory, kept at $5^{\circ} \mathrm{C}$, and processed for culture and cell counts the same day.

\section{Laboratory procedures}

Somatic cell counts were estimated by the direct microscopic method ${ }^{10}$. A cell count greater than $0.42 \times 10^{6}$ per m $\ell$ was considered to be significant.

For bacteriological analysis, $0.1 \mathrm{~m} \ell$ of thoroughly-mixed quarter milk sample was inoculated onto blood agar medium. The inoculated blood agar plates were incubated aerobically at $37^{\circ} \mathrm{C}$ for $24-48$ hours and examined for bacterial growth. To eliminate the possibility of chance contaminants, an isolate was not considered significant if fewer than 50 colonies grew from the sample of milk.

Staphylococci were identified by colony morphology, Gram stain and catalase test. Staphylococci isolates were tested for the coagulase reaction using both the slide and tube methods. Coagulase-positive staphylococci were further tested for mannitol fermentation using mannitol salt agar. They were also tested for their susceptibility to $5 \mu \mathrm{g}$ of novobiocin and 300 units of polymyxin B. Staphylococci that were coagulase-positive, fermented 
mannitol, were susceptible to $5 \mu \mathrm{g}$ of novobiocin and resistant to 300 units of polymyxin B, were recorded as $S$. aureus. $S$. intermedius and some strains of $S$. hyicus that are also coagulase-positive were differentiated from $S$. aureus by mannitol fermentation and susceptibility to $5 \mu \mathrm{g}$ of novobiocin and 300 units of polymyxin B. Coagulase-negative staphylococci were identified to species level by carrying out a wide range of tests ${ }^{7}$.

Other organisms were identified following standard procedures ${ }^{5}$. In addition, the API 20E kits (bio Merieux, France) were used to confirm the identity of the enteric bacteria. Antibiograms of coagulasenegative staphylococci isolates were determined using the Kirby-Bauer disc diffusion technique ${ }^{2}$ with the following antibiotics: penicillin (10 iu), tetracycline $(30 \mu \mathrm{g})$, streptomycin $(10 \mu \mathrm{g})$, lincomycin $(2 \mu \mathrm{g})$, neomycin $(30 \mu \mathrm{g})$, erythromycin $(15 \mu \mathrm{g})$ and cloxacillin $(5 \mu \mathrm{g})$, using diagnostic sensitivity test agar.

Cows were considered to have subclinical mastitis if the quarter milk and udder were macroscopically normal but the milk had a high somatic cell count $\left(>0.42 \times 10^{6}\right.$ cells $\left./ \mathrm{m} \ell\right)$ with a significant bacterial growth.

\section{RESULTS}

Thirty-five quarter milk samples, 1 of which had no significant growth, were from clinical mastitis cases, and 371 quarter milk samples were from cows with subclinical mastitis. The most frequent pathogens isolated in clinical mastitis were the enteric bacteria, with E. coli predominant, followed by coagulase-negative staphylococci and then $S$. aureus, as shown in Table 1 . In cases of subclinical mastitis, S. aureus and coagulase-negative staphylococci were most commonly isolated, and were isolated at nearly the same rates. Coagulase-negative staphylococci were isolated at a higher rate in subclinical mastitis than in clinical mastitis, but the difference was not significant $(P=0.26)$.

Table 1: Isolation rates of bacteria associated with clinical and subclinical mastitis.

\begin{tabular}{lcc} 
Bacteria isolated & Clinical mastitis & Subclinical mastitis \\
\hline S. aureus & $6(17.1 \%)$ & $127(34.2 \%)$ \\
Coagulase-negative staphylococci & $8(22.9 \%)$ & $123(33.2 \%)$ \\
Streptococci & $5(14.3 \%)$ & $41(11.1 \%)$ \\
Enteric bacteria & $11(31.4 \%)$ & $20(5.4 \%)$ \\
Bacillus species & $0(0 \%)$ & $48(12.9 \%)$ \\
Others & $4(11.4 \%)$ & $12(3.2 \%)$ \\
No significant growth & $1(2.9)$ & $0(0 \%)$ \\
Total & 35 & 371 \\
\hline
\end{tabular}

Bacillus species were only isolated in milk samples from subclinical mastitis.

Coagulase-negative staphylococci were observed in mixed infections with other bacteria in $2.2 \%$ of the 405 milk samples, with significant bacterial growth from clinical and subclinical mastitis. Coagulase-negative staphylococci were isolated together with Bacillus species in 6 of the 9 mixed infection cases. The correlation between cell counts and culture results is shown in Table 2 . About $60 \%$ of the milk samples with significant bacterial isolations had very high somatic cell counts $\left(>1.0 \times 10^{6}\right.$ cells $\left./ \mathrm{m} \ell\right)$. About $95 \%$ of the milk samples from which the 131 coagulase-negative staphylococci were isolated had correspondingly high somatic cell counts $\left(>0.42 \times 10^{6}\right.$ cells $\left./ \mathrm{m} \ell\right)$.

The coagulase-negative staphylococci species isolated most frequently were $S$. chromogenes $(7.9 \%)$, followed by S. epidermidis $(7.4 \%)$ and S. hominis $(5.9 \%)$, as shown in Table 3. They were all associated with high somatic cell counts (Table 4). $S$. chromogenes and S. epidermidis were isolated more often from subclinical than clinical mastitis, whereas $S$. hominis was only isolated from cases of subclinical mastitis. The other coagulase-negative staphylococci were also isolated mainly from subclinical mastitis cases. All the coagulase-negative staphylococci isolates were susceptible to cloxacillin and erythromycin, and over $90 \%$ of the isolates were susceptible to neomycin, penicillin and streptomycin (Table 5). The highest resistance was to tetracycline, followed by lincomycin. About $8 \%$ of the isolates were resistant to both penicillin and streptomycin.

\section{DISCUSSION}

Coagulase-negative staphylococci are normal flora of healthy teat skin and constitute a constant source of bacteria to colonise the teat end. The results of the current study show that coagulase-negative staphylococci play a major role in causing bovine mastitis, since they were isolated in high percentages of $22.9 \%$ and $33.2 \%$ in clinical and subclinical mastitis respectively, and $95 \%$ of the isolates were from milk samples with high somatic cell counts. However, a lower isolation rate of $11.9 \%$ of coagulase-negative staphylococci was observed in milk samples from subclinical mastitis cases in Bloemfontein dairy herds in South Africa ${ }^{11}$. The results of the current study suggest that the coagulase-negative staphylococci were responsible for udder and not teat canal infections, since most of the bacteria were isolated from quarters with a high somatic cell count, and the organisms were only rarely involved in mixed infections.

Since the most frequent coagulasenegative staphylococcus species isolated were S. chromogenes, S. epidermidis and $S$. hominis, all of which were associated with high somatic cell counts, these 3 species appear to be the most important coagulase-negative staphylococci in bovine mastitis. S. epidermidis and S. chromogenes are major staphylococci found living on human skin, and most probably origi-

Table 2: Correlation of cell counts and cultural results on quarter milk samples.

\begin{tabular}{|c|c|c|c|c|c|}
\hline \multirow{3}{*}{ Isolates } & \multicolumn{5}{|c|}{ Cell counts $\left(\times 10^{6}\right)$ per $\mathrm{m} \ell$} \\
\hline & \multirow{2}{*}{$\frac{<0.42}{\text { Clinical mastitis }}$} & \multicolumn{2}{|c|}{$0.42-1.0$} & \multicolumn{2}{|c|}{$>1.0$} \\
\hline & & Clinical mastitis & Subclinical mastitis & Clinical mastitis & Subclinical mastitis \\
\hline No significant growth & 0 & 1 & 0 & 0 & 0 \\
\hline S. aureus & 5 & 2 & 41 & 4 & 81 \\
\hline $\mathrm{CNS}^{*}$ & 7 & 1 & 39 & 7 & 77 \\
\hline Streptococci & 2 & 3 & 16 & 2 & 23 \\
\hline Enteric bacteria & 1 & 2 & 9 & 9 & 10 \\
\hline Bacillus species & 3 & 0 & 18 & 0 & 27 \\
\hline Others & 1 & 0 & 6 & 4 & 5 \\
\hline Total & 19 & 9 & 129 & 26 & 223 \\
\hline
\end{tabular}

${ }^{*} \mathrm{CNS}$ = coagulase-negative staphylococci. 
Table 3: Isolation of coagulase-negative staphylococci in clinical and subclinical mastitis.

\begin{tabular}{|c|c|c|c|}
\hline & Clinical isolate & Subclinical mastitis & Total mastitis \\
\hline S. chromogenes & $2(13.3 \%)$ & $30(25.9 \%)$ & 32 \\
\hline S. epidermidis & $5(33.3 \%)$ & $25(21.6 \%)$ & 30 \\
\hline S. hominis & $0(0.0 \%)$ & $24(20.7 \%)$ & 24 \\
\hline S. hyicus & $0(0.0 \%)$ & $11(9.5 \%)$ & 11 \\
\hline S. xylosus & $6(40.0 \%)$ & $3(2.6 \%)$ & 9 \\
\hline S. saprophyticus & $0(0.0 \%)$ & $5(4.3 \%)$ & 5 \\
\hline S. lentus & $0(0.0 \%)$ & $4(3.5 \%)$ & 4 \\
\hline S. sciuri & $0(0.0 \%)$ & $2(1.7 \%)$ & 2 \\
\hline S. caseolyticus & $1(6.7 \%)$ & $1(0.9 \%)$ & 2 \\
\hline S. simulans & $0(0.0 \%)$ & $1(0.9 \%)$ & 1 \\
\hline S. muscae & $0(0.0 \%)$ & $1(0.9 \%)$ & 1 \\
\hline S. kloosii & $1(6.7 \%)$ & $0(0.0 \%)$ & 1 \\
\hline Unidentified CNS* & $0(0.0 \%)$ & $9(7.8 \%)$ & 9 \\
\hline Total & 15 & 116 & 131 \\
\hline
\end{tabular}

${ }^{*} \mathrm{CNS}=$ coagulase-negative staphylococci.

Table 4: Correlation of cell counts and cultural results for quarter milk samples.

\begin{tabular}{|c|c|c|c|c|c|}
\hline \multirow{3}{*}{ Isolates } & \multicolumn{5}{|c|}{ Cell counts $\left(\times 10^{6}\right)$ per $\mathrm{m} \ell$} \\
\hline & \multirow{2}{*}{$\frac{<0.42}{\text { Clinical mastitis }}$} & \multicolumn{2}{|c|}{$0.42-1.0$} & \multicolumn{2}{|c|}{$>1.0$} \\
\hline & & Clinical mastitis & Subclinical mastitis & Clinical mastitis & Subclinical mastitis \\
\hline S. chromogenes & 0 & 0 & 0 & 2 & 30 \\
\hline S. epidermidis & 0 & 0 & 0 & 5 & 25 \\
\hline S. hominis & 0 & 0 & 2 & 0 & 22 \\
\hline Other $\mathrm{CNS}^{*}$ & 7 & 1 & 37 & 0 & 0 \\
\hline Total & 7 & 1 & 39 & 7 & 77 \\
\hline
\end{tabular}

${ }^{\star} \mathrm{CNS}=$ coagulase-negative staphylococci.

nated from the milkers. S. chromogenes has also been observed to be the most common coagulase-negative staphylococcus in bovine intramammary infections ${ }^{12}$.

The results of the present study show that subclinical mastitis is more prevalent than clinical mastitis. Similar results were observed in an earlier study carried out in Zimbabwe ${ }^{9}$, where clinical mastitis accounted for only $8.1 \%$ of the total mastitis cases. In the present study, coagulase-negative staphylococci were isolated at a high rate in both clinical and subclinical mastitis, although some studies have shown low isolation rates of coagulase-negative staphylococci associated with clinical mastitis. For example, a study in USA showed $8.1 \%$ coagulasenegative staphylococci associated with clinical mastitis ${ }^{12}$. The high isolation rate of coagulase-negative staphylococci isolates in pure culture in the present study can be attributed to the fact that the organisms have been shown to exert a protective effect for the udder against superinfection by E. coli, S. agalactiae, or S. aureus ${ }^{3,8}$.

The observation that all the coagulasenegative staphylococci isolates were sensitive to erythromycin is consistent with the observation in a study carried out in the USA ${ }^{12}$. However, tetracycline resistance was higher $(17.6 \%)$ in the present study than in the study carried out in the $\mathrm{USA}^{12}$, where $6.9 \%$ resistance was observed, which was attributed to plasmids. The high resistance of coagulase-negative staphylococci to tetracycline in the current study is probably because this drug is commonly used for treatment of

Table 5: Antibiotic susceptibilities of coagulase-negative staphylococci isolates from bovine milk.

\begin{tabular}{lcc}
\hline Antibiotic & No. sensitive & Percentage \\
\hline Cloxacillin $(5 \mu \mathrm{g})$ & 131 & 100 \\
Erythromycin $(15 \mu \mathrm{g})$ & 131 & 100 \\
Neomycin $(30 \mu \mathrm{g})$ & 130 & 99.2 \\
Penicillin $(10 \mathrm{iu})$ & 120 & 91.6 \\
Streptomycin $(10 \mu \mathrm{g})$ & 120 & 91.6 \\
Lincomycin $(2 \mu \mathrm{g})$ & 113 & 86.3 \\
Tetracycline $(30 \mu \mathrm{g})$ & 108 & 82.4 \\
\hline
\end{tabular}

animals in Zimbabwe. Cloxacillin, erythromycin and neomycin are antibiotics that can be used to treat mastitis caused by coagulase-negative staphylococci in Zimbabwe, since nearly all the isolates were susceptible to these drugs.

The results of the present study suggest that coagulase-negative staphylococci play a major role in causing clinical and subclinical bovine mastitis, and the organisms should be considered potential udder pathogens in the routine culturing of milk samples, for which antibiotic susceptibilities should be carried out.

\section{ACKNOWLEDGEMENTS}

We thank the Central Veterinary Laboratory Bacteriology staff for their technical assistance.

\section{REFERENCES}

1. Badenhorst B 1978 The mastitis control scheme in Mashonaland: analysis of results over three years. Rhodesian Veterinary Journal 9: 32-34

2. Bauer A W, Kirby W M M 1966 Antibiotic susceptibility testing by a single standard disc method. American Journal of Clinical Pathology 36: 493-496

3. Bramley A J 1978 The effect of subclinical Staphylococcus epidermidis infection of the lactating bovine udder on its susceptibility to infection with Streptococcus agalactiae or Escherichia coli. British Veterinary Journal 134: 146-151

4. Bryson R W, Thomson J W 1976 Laboratory 
and field control of clinical mastitis in dairy cows around Bulawayo. Journal of South African Veterinary Association 47: 201-203

5. Cheesbrough M 1984 Medical laboratory manual for tropical countries, 2: microbiology (1st edn). Butterworth, Borough Green

6. Dodd F D, Westgarth D R, Griffin T K 1977 Strategy of mastitis control. Journal of the American Veterinary Medical Association 170: 1124-1128

7. Kloos W E, Lambe D W 1991 Manual of clinical microbiology. American Society for
Microbiology, Washington, DC

8. Matthews K R, Harmon R J, Langlois B E 1991 Effect of naturally occurring coagulase-negative staphylococci infections on new infections by mastitis pathogens in the bovine. Journal of Dairy Science 74: 1855-1859

9. Perry B D, Carter M E, Hill F W G, Milne J A C 1987 Mastitis and milk production in cattle in a communal land of Zimbabwe. British Veterinary Journal 143: 44-50

10. Prescott S C, Breed R S 1910 The determination of the number of body cells in milk by a direct method. Journal of Infectious Diseases 7: 632-637

11. Swartz R, Jooste P J, Novello J C 1984 Prevalence and types of bacteria associated with subclinical mastitis in Bloemfontein dairy herds. Journal of the South African Veterinary Association 55: 61-64

12. Todhunter D A, Cantwell L L, Smith K L, Hoblet K H, Hogan J S 1993 Characteristics of coagulase-negative staphylococci isolated from bovine intramammary infections. Veterinary Microbiology 34: 373-380 